\title{
Cost and Returns Analysis for Small-scale Dry Season Tomato Production in Onitsha Agricultural Zone of Anambra state
}

\author{
Cecilia A. Nwigwe ${ }^{1 *}$, Nkiru T. Meludu ${ }^{1}$, Chinyere C. Okeke ${ }^{1}$, Ngozi J. Obiekwe $^{1}$ \\ ${ }^{1}$ Department of Agricultural Economics and Extension, Nnamdi Azikiwe University, Awka, Anambra State, Nigeria.
}

\begin{abstract}
How to cite this paper: Cecilia $A$ Nwigwe, Nkiru T. Meludu, Chinyere C. Okeke, and Ngozi J. Obiekwe. (2020) Cost and Returns Analysis for Small-scale Dry Season Tomato Production in Onitsha Agricultural Zone of Anambra state. International Journal of the Science of Food and Agriculture, 4(2), 129-137. DOI: $10.26855 /$ ijfsa.2020.06.003
\end{abstract}

Received: March 6, 2020

Accepted: March 27, 2020

Published: April 2, 2020

*Corresponding author: Cecilia A Nwigwe, Department of Agricultural Economics and Extension, Nnamdi Azikiwe University, Awka, Anambra State, Nigeria.

Email: akuchius@yahoo.com

\begin{abstract}
The study analyzed the cost and returns of dry season tomato production by small scale farmers in Onitsha Agricultural Zone of Anambra State, Nigeria. Eighty farmers were randomly selected for the study and data were analyzed, using descriptive analysis and profitability analysis. The results showed that the mean age of the farmers was 42 years, implying that they were in their productive ages. The respondents were fairly educated as about 45 percent of them had secondary school education. The result of the profitability analysis revealed average gross margin and net income of N670,103.72 and N657,454.62 for tomato intercrop farmers respectively; average gross margin and net margin of N589,910.14 and N577,261.04 respectively, for sole tomato enterprise farmers respectively. This indicated that dry season tomato production was a profitable venture in the study area. The analysis further identified inadequate farm credit and poor storage facilities as the main problems faced by the farmers. The study therefore recommends that farmers should be encouraged to form cooperative societies so as to enable them obtain loans from commercial banks and agricultural banks a1 regulated interest rates. Government should also focus research on viable methods of storing tomatoes and other vegetables, so as to encourage farmers to produce more and ensure food security.
\end{abstract}

\section{Keywords}

Tomato Production, Dry Season, Small-Scale, Nigeria

\section{Introduction}

Tomato (Lycopersicon esculentum Mill.) is one of the most cultivated vegetable in most regions of the world, ranking second in importance in many countries (Ibeawuchi, 2015). In Nigeria, an annual total area of one million hectares is reportedly used for its cultivation and it makes up about 18 percent of the average daily consumption of vegetables in Nigerian homes (Chidi, 2012). Nigeria is also ranked second largest producer of tomato in Africa and thirtieth largest in the world, producing 1.701 million tonnes of tomato annually at an average of 25-30 tonnes per hectare (FAO, 2010). Tomato is perhaps the most important popular vegetable crop grown all over the country. Tomatoes are important in the daily meal preparation since it can be eaten raw or cooked. Larger quantities are used to produce soups, juice and sauces, ketchups, purees and paste. It can be used in canning industries; green tomatoes are used for prickles and preserve. The seeds which are extracted from the pulp and its residues contain $24 \%$ oil, which is used for salad dressing and in the manufacturing of margarine and soap. The residual press cake 
is used as stock feed as well as fertilizer. In addition, vegetable such as tomato, apart from being consumed at home, also earns foreign exchange to the producer countries, due to exportation. Nwalieji et al., (2015) opined that both wet and dry season tomato cropping systems, contribute immensely to the national requirement, though bulk production is from the dry season cropping.

In Nigeria, there are two distinct seasons, the rainy and dry seasons. The rainy season is the normal cropping season and starts from April and ends in October, while the dry season starts from November and ends in April. During the rainy season, the production of tomato is high; resulting in saturation of the market, but during the dry season, there is usually the scarcity of this important farm product, thereby leading to a high price due to short supply. This seasonality has resulted in food insecurity, which is a challenge to sustainable food production. It has been found that most farmers do not want to go into large scale vegetable production because they are apprehensive of risk of cropping during the dry season. This has made farmers to grow vegetables as an intercrop of low significance as a way of avoiding risks (Onoh et al., 2016). There is therefore need to encourage dry season tomato cropping system so as to bridge the demand and supply gap. Dry season tomato production in Anambra State is done mainly in swampy (Fadama) areas along river banks. This activity is both an income earner as well as a source of employment to a large proportion of the populace or otherwise, underemployed labour force (Nwalieji et al., 2015). The question now is: what potential do dry-season tomato production has and how profitable is it? What problems militate against its production in the study area? The possible answers are what this research seeks to provide.

Quite a number of studies have investigated the cost and returns of small-scale dry season vegetable production (Mazza et al., 2015; Usman and Bakari, 2013; Ehirim et al., 2014; Onoh et al., 2016; Samshunnahar et al., 2016; Tsoho and Salau, 2012; Ajayi and Nwalieji, 2010; Nwalieji et al., 2015; Sanusi and Ayinde, 2013). The results from most of these studies highlighted the need to extend the farming season beyond the rainy season through irrigated agriculture, since self-sufficiency in food production based on rain-fed agriculture is difficult to achieve (Ajayi and Nwalieji, 2010).

\section{Methodology}

\subsection{Study area}

The study area was Anambra State, which is located in the South east geopolitical zone of Nigeria, with its capital in Awka. It has an estimated population of 7,821,850 million people, which stretches over about 60 kilometers between surrounding communities. The state is bordered by Delta State to the West, Imo State to the South, Enugu State to the East and Kogi State to the North. It has 4 agricultural zones namely Anambra, Awka, Onitsha and Aguata. The climate is typically equatorial, with two main seasons, the dry and the rainy seasons. The state experiences dry season, from late October to early May and has at least, six dry months in the year; the vegetation consists of rain forest. Other parts consist of wooden savannah and grasslands. The state is drained by five major rivers and their tributaries. These are the River Niger, Anambra River, Mama/Ezu River, Idemili River and River Ulasi. In addition to these, there are smaller perennial streams like the Oyi, Nkisi and Obizi. In-land valley ponds and lake occur, with the Agulu Lake, draining a collection of towns in the state (Nwadukwe, 2000). The people are predominantly farmers, most of who engage in cultivation of arable crops such as cassava, yam, maize, rice, okra, tomatoes and pepper, while some engage in livestock production such as piggery, poultry and fish farming.

\subsection{Sampling procedure and sample size}

A multi-stage sampling procedure was adopted in the selection of the sample size. In the first stage, Onitsha agricultural zone was purposively selected for the study because of the high intensity of tomato production in the area and also, the proximity to swampy (fadama) areas, which supports tomato production. All tomato producers in Onitsha agricultural zone formed the population of the study. Also, based on the same reasons, two blocks (Ogbaru and Idemili south) were also purposively selected from the Onitsha agricultural zone. From each of the two blocks, two circles that were actively involved in the activities of Fadama project were selected, using simple random sampling technique. This indicates that a total of four circles were involved in the study. A list of farmers in the four circles was obtained from the headquarters of Anambra State Agricultural Development Project (ASADEP); a total of eighty respondents (twenty respondents from each of the four circles) was selected, using 
simple random sampling techniques.

\subsection{Method of Data Collection}

Primary data were used for the study. These were obtained through administration of questionnaire to tomato farmers in the study area. The questionnaire contained pertinent questions that border on production pattern and inputs; socio-economic characteristics of the producers as well as constraints faced by the respondents in tomato production. Questionnaire were administered by the researcher and two trained enumerators between August and November, 2016.

\subsection{Analytical Tools and Techniques}

The following analytical tools were employed in the analysis:

Descriptive statistics: the uses of frequency distributions and percentages, as well as mean distributions were adopted to describe the socio-economic characteristics of tomato farmers, describe tomato planting pattern and constraints to tomato production in the study area.

Budgetary Analysis: Analysis of costs and returns was used to estimate the costs and returns while gross and net margins as well as rate of return to investment were used to measure profitability of tomato production in the study area.

Costs are expenses incurred in the operations of a production unit. Variable cost items included seeds, labour, fertilizer and pesticides. The fixed cost items included hoes, cutlasses, baskets, sprayers and land. The depreciated values of the fixed cost items were also estimated. However, revenue is the price per unit output multiply by quantity of output. The gross margin of an enterprise gives the profit that is likely to be obtained from the production process. Afolami and Ayinde (2002) defined gross margin as the difference between gross farm income (GFI) and the Total Variable Cost (TVC); while net farm income (NFI) was defined as the difference between gross margin and total fixed production cost. It is expressed as follows:

$\mathrm{GM}=\mathrm{TR}-\mathrm{TVC}$

Where:

$\mathrm{GM}=$ Gross margim $(\mathrm{N} / \mathrm{Ha})$

$\mathrm{TR}=$ Total Revenue $(\mathrm{N} / \mathrm{Ha})$

$\mathrm{TVC}=$ Total Variable Cost $(\mathrm{N} / \mathrm{Ha})$

And

$\mathrm{NFI}=\mathrm{GM}-\mathrm{TFC}$

Farm Gross Ratio $=$ GM/TR

Net profit $(\pi)=$ Total Revenue $(\mathrm{TR})-$ Total Cost $(\mathrm{TC})$

Rate of Returns $(\mathrm{ROR})=(\mathrm{TR} / \mathrm{TC})$

Rate of Return on Investment $(\mathrm{RORI})=(\mathrm{NM} / \mathrm{TC})$

\section{Results and discussion}

\subsection{Socio-economic Characteristics of Tomato Farmers, Planting Methods and Farm Related Variables:}

Table 1 showed that more males (79\%) were involved in tomato production than females (17\%). This implies that tomato production is male-dominated in the study area. The age of the farmer, in the opinion of Adewumi and Omotosho (2002), is expected to affect his productivity and labour. It also affects the adoption of innovation in traditional farming. The average age of the respondents was found to be 42 years. This depicts that the respondents were still within the productive age, to carry out their farming and marketing activities. However, given the ageing nature of the sampled respondents, there might be a reduction in the effective labour force for agricultural production in the study area. This might have implication for available family labour force. This is in conformity with results from the study by Ofor et al., 2015; Imoh (2004); Onu et al., (2000); Nwalieji and Ajayi (2008); Ehirim et al., 2014; Onoh et al., 2016; Mgbada (2010); Tsoho and Salau (2012), which revealed that the average age of farmers in Nigeria is between 41 and 50 years. The mean household size was 8 persons, which is a significant source of human power utilized in farming operations (Balogun et al., 2012). It is a cheaper means of providing farm labour and reducing labour cost (Nwaobiala and Ogbonna (2014). This is in conformity with results from the study by Ehirim et al., 2014; Onoh et al. 2016; Osuji et al., 2012; Samshumahar et al., 2014), 
which revealed a large household size, between 5 and 10, among sampled respondents. Majority of the farmers in the area were young and energetic male farmers with reasonable literacy level. Education status showed that majority of the respondents $(45.7 \%)$ had secondary education, which is a significant factor for adoption of new and improved technology (Akingbile and Ndaghu 2000. Adejo et al., (2012) and Tsoho and Salau (2012), also discovered high literacy level among farmers and hence, reported that the more educated farmers are, the more they become willing to accept innovations. Studies by Williams et al., (2018); Onyewaku and Mbuba (1991); Challa (2013); Eke-Okoro and Njoku (2012); revealed that extension agents provide information and farm inputs to farmers; and this has positive impact on farmer's productivity. In the study area, about 77.5 percent of the respondents had contact with extension agents, which means that the respondents benefited from extension services. Farming experience is expected to have a considerable effect on farmers' production efficiency. About 45 percent of the respondents had less than five years of experience in tomato production. Similar results were also found in studies by Nwalieji et al., (2015) and Ehirim et al., (2014), who worked on small-scale vegetable production in Nigeria. This may affect their efficiency, because the more experienced a farmer is, the more efficient he may be on the farm and vice versa. Analysis of the farm size revealed that the average farm size was $0.80 \mathrm{Ha}$. This means that majority of the respondents were small scaled and command farm holdings of less than 1 hectare. This implied that mechanized farm production among the respondents could not be feasible. Similar results were also found in studies by Williams et al., (2017); Nwaobiala and Ogbonna (2014); Ehirim et al., (2014) and Tsoho and Salau, (2012).

Further, results obtained from the study shows that $65 \%$ of the respondents practiced crop rotation while $15 \%$ percent did not. This may be due to annual nature of the crop and the disposition of the tomato farmers to tomato production. Table 1 shows that majority of the farmers practiced sole cropping while only 3.75 percent of the farmers practiced both sole and intercropping. The intercropping system practiced by tomato farmers could help them diversify farming activities, a situation which could increase accruable total farm revenue. Results also show that $25.8 \%$ of the sampled farmers engaged in tomato production, with the main objective of income generation while about $65 \%$ indicated income as well as meeting the family needs objective. Thus, it can be opined that farmers engage in tomato production in order to meet family needs and to have enough income for their upkeep.

Table 1: Distribution of Tomato Farmers by Personal and Farm Characteristics

\begin{tabular}{|c|c|c|c|}
\hline Variable & Frequency & Percentage & Mean \\
\hline \multicolumn{4}{|l|}{ Gender } \\
\hline Male & 63 & 79.0 & \\
\hline Female & 17 & 21.0 & \\
\hline \multicolumn{4}{|l|}{ Age } \\
\hline $20-29$ & 13 & 17.3 & \\
\hline 3039 & 6 & 7.4 & \\
\hline $40-49$ & 44 & 54.3 & \\
\hline 50 - above & 17 & 21.0 & 42 \\
\hline \multicolumn{4}{|l|}{ Marital Status } \\
\hline Married & 76 & 95.0 & \\
\hline Divorced & 2 & 2.5 & \\
\hline Widowed & 2 & 2.5 & \\
\hline \multicolumn{4}{|l|}{ Education } \\
\hline No formal education & 16 & 19.8 & \\
\hline Primary education & 20 & 26.0 & \\
\hline
\end{tabular}


Secondary education

Tertiary education

Household size

$$
\begin{gathered}
1-5 \\
6-10 \\
11-15 \\
16-20
\end{gathered}
$$

Farm size (Ha)

$$
\begin{aligned}
& 0.1-1.0 \\
& 1.1-2.0 \\
& 2.1-3.0
\end{aligned}
$$

Tomato Farming Experience (Years)

$$
\begin{aligned}
& 1-10 \\
& 11-20 \\
& 21-30 \\
& 31-40 \\
& >40
\end{aligned}
$$

Extension visits

$$
\begin{aligned}
& \text { Yes } \\
& \text { No }
\end{aligned}
$$

Plot rotation

$$
\text { Yes }
$$

No

Planting methods

$$
\begin{aligned}
& \text { Sole cropping } \\
& \text { Intercropping }
\end{aligned}
$$

Both

Objective of cultivating

$$
\text { tomato }
$$

Income only

To meet family needs

$$
\text { Both }
$$

45.7

8.6

22.5

37.5

8

22.5

0

37.95

3.1

25.5

0.8

66.7

26.7

0.8

3.3

2.5

4
65.0

31.25

3.75

3

25.8

9.2

65.0

Source: Field survey, 2016

\subsection{Estimation of Profitability of Tomato Production in the Study Area}


Table 2 shows the gross margin in Naira/season and the various cost of inputs used in tomato production for the tomato intercrop and sole tomato. The breakdown of the total costs and returns to tomato farmers in the study area is as shown in Table 2. The tomato farmers (in tomato enterprise combination) incurred a total of N279,423.78 and earned a total revenue of N936,878.40. Consequently, the tomato farmer realized a profit of N657,454.62 per season. The total variable cost and total revenue for tomato-intercrop enterprise per production season was N266,774.68 and N936,878.40 respectively, while the gross margin per was N670,103.72 per season. However, the tomato farmer (in sole tomato enterprise) incurred a total cost of N219,609.58 and earned a total revenue of N796,870.62. Consequently, the tomato farmers realized a profit of N577,261.04/ season. The total variable cost and total revenue for sole tomato enterprise per production season was N206,906.48 and N796,870.62 respectively while the gross margin per farmer was N589,910.14 per/season. The Farm gross ratio for tomato intercrop enterprise and sole tomato enterprise were found to be 0.71 and 0.74 respectively. The ratio showed that the total farm cost was about $7 \%$ of the gross revenue, which is in line with Olukosi and Erhabor (2008), which states that a gross ratio of less than one is desirable for any farm business. Therefore, based on the information in Table 2, it is obvious that dry season tomato production was a profitable venture in the study area.

The rate of returns (ROR) value of 3.35 means that every N1 invested in tomato intercrop enterprise in the study area returns a revenue of N3.35 to the farmer while the rate of returns value of 3.62 means that every N1 invested in sole tomato production in the study area returns a revenue of N3.62.

Table 2: Gross and Net Margin per Production Season of Tomato Farmers in Anambra State

\begin{tabular}{|c|c|c|}
\hline Variable & Tomato Intercrop (N) & Tomato Sole $(\mathrm{N})$ \\
\hline Total Revenue & $936,878.40$ & $796,870.62$ \\
\hline \multicolumn{3}{|l|}{ Variable Cost } \\
\hline Cost of Land & $17,426.18$ & $12,572.44$ \\
\hline Cost of seed & $11,330.46$ & 7980.60 \\
\hline Labour & $223,747.30$ & $174,604.18$ \\
\hline Insecticide & $3,724.24$ & 2.980 .12 \\
\hline Fertilizer & $10,546.50$ & $8,868.14$ \\
\hline Total Variable Cost & $266,774.68$ & $206,960.48$ \\
\hline \multicolumn{3}{|l|}{ Fixed cost (Depreciated) } \\
\hline Hoe & 678.70 & 678.70 \\
\hline Cutlass & 1,120 & 1,120 \\
\hline Knapsack sprayer & 4,860 & 4,860 \\
\hline Bowls & 320.40 & 320.40 \\
\hline Basket & 336.70 & 336.70 \\
\hline Gloves & 40.50 & 40.50 \\
\hline Others & $5,292.20$ & $5,292.20$ \\
\hline Total Fixed Cost & $12,649.1$ & $12,649.1$ \\
\hline Total cost & $279,423.78$ & $219,609.59$ \\
\hline Gross Margin/season & $670,103.72$ & $589,910.14$ \\
\hline Net Margin/season & $657,454.62$ & $577,261.04$ \\
\hline Farm Gross Ratio & 0.71 & 0.74 \\
\hline ROR & 3.35 & 3.62 \\
\hline RORI & 2.35 & 2.62 \\
\hline
\end{tabular}

Source: Field Survey, 2016

\subsection{Description of Tomato Farmers according to the Constraints in Tomato Production}


The most significant constraint faced by the farmers in the study area was inadequate farm credit. The result in Table 3 showed that majority of the farmers $(87.5 \%)$ of the respondents were constrained by this factor. Credit is one of the essential ingredients in agricultural production. It helps to improve capacity utilization and also provide opportunity for purchase of adequate inputs for more efficient production. It can also be used to expand farm business, to take advantage of economies of scale, as well as acquisition of new technologies and payment for hired labour and related services. It is also needed to acquire capital assets like farm machinery and equipment and for working capital to purchase improved seedlings, fertilizer and agrochemicals (Sanusi and Ayinde, 2013; Okeleye et al., 2016; Spaldon et al., 2015). This result is in line with the results from the study by Usman and Bakari (2013) and Sanusi and Ayinde (2013), who reported that, inadequate capital hinders tomato farmers from expanding their business. This was followed by poor storage facilities. Problem of inadequate storage of tomatoes abound in the study area. About $60 \%$ of the farmers had problems in storing their produce (Table 3 ). This problem causes the price of tomatoes to fluctuate with season. Farmers are forced to sell their produce during harvest at a very low price. This problem could be addressed if research in agricultural engineering and food technology could be focused on viable methods of storing tomatoes and other vegetables like pepper, okra etc., which are highly perishable by nature. Results from studies by Ehirim et al., (2014) and Onoh et al., (2016), also reported that inadequate storage facility is a major constraint facing vegetable farmers. About $52.5 \%$ of the respondents pointed out high incidence of pests and diseases, as a constraining factor. Farmers require pesticides, herbicides etc, to enhance vegetable production, but the problem is that these farm inputs are either unavailable or purchased at a very exorbitant rate. This implies that there will be reduction in yield and income accruable to the tomato farmers if this problem is not adequately tackled. Another problem reported by the farmers was shortage/high cost of inputs. About $47.5 \%$ of the respondents had problems in sourcing for inputs such as viable and disease-resistant seeds, fertilizer, pesticides and insecticides, for improved crop establishment and to combat pest and diseases outbreak. In order to address these problems, a mechanism ensuring availability of inputs should be instituted by the government, given the time-bound nature of tomato farming, so that production and productivity may be improved.

Table 3: Distribution of Respondents by Constraints in Tomato Production

\begin{tabular}{|c|c|c|c|}
\hline Constraints & Frequency & Percentage & Rank \\
\hline \multicolumn{4}{|c|}{ Inadequate Farm Credit } \\
\hline Yes & 70 & 87.5 & 1 \\
\hline No & 10 & 12.5 & \\
\hline Total & 80 & 100 & \\
\hline \multicolumn{4}{|c|}{ Poor Storage Facilities } \\
\hline Yes & 48 & 60.0 & 2 \\
\hline No & 32 & 40.0 & \\
\hline Total & 80 & 100 & \\
\hline \multicolumn{4}{|l|}{ Disease/Pest } \\
\hline Yes & 42 & 52.5 & 3 \\
\hline No & 38 & 47.5 & \\
\hline \multicolumn{4}{|c|}{ Input supply/Production cost } \\
\hline Yes & 38 & 47.5 & 4 \\
\hline No & 42 & 52.5 & \\
\hline Total & & & \\
\hline
\end{tabular}

Source: Field Survey, 2016 (Multiple responses)

\section{Conclusion and Recommendations}


The results indicated that majority of the tomato farmers in the study area were married and also males in their active ages. The study also showed that most of the respondents were small-scale farmers, with little experience in tomato production. However, the respondents make good farm profit, with average gross margin and net farm income of N670,103.72 and N657,454.62 for tomato intercrop farmers respectively; average gross margin and net margin of N589,910.14 and N577,261.04 respectively, for sole tomato enterprise. While inadequacy of farm credit was identified as the most significant problem among the respondents, input supply/production cost was the least significant constraint. The study therefore, recommended that farmers should be encouraged to form cooperative societies so as to enable them obtain loans from commercial banks and agricultural and rural cooperative bank, at regulated interest rate. Profitability analysis revealed that tomato production was profitable in the study area, hence, it was concluded that, if the various constraints reported by the farmers are addressed forthwith, production of tomato in the study area will remain on the increase and consequently, the living standard of these farmers would be positively enhanced, with its resultant, food security.

\section{References}

[1] Ibeawuchi, C. A (2015) Fruit and Vegetable Crop Production in Nigeria: The Gains., Journal of Biology, Agriculture and HealthCare, 196-208

[2] Chidi, A (2012) Tomato, nutritious vegetable. Seventeen Nigerian Economic Summit; Alafrican post web team; Pp 1-3

[3] Food and Agriculture Organization (FAO) (2010) (Global and national tomato production), GTIS (Trade for fresh tomato-code 0702000), tomato news (Tomato products consumption)

[4] Nwalieji, H.U, Okeke, M.N and Uzuegbunam, C.O (2015) Comparative profit analysis of dry and rainy season okra (Abelmoschus Esculentus) production among women in Ayamelum Local Government Area of Anambra State, Nigeria; IOSR Journal of Agriculture and Veterinary Science (IOSR-JAVS) e-ISSN: 2319-2380, p-ISSN:2319-2372. Volume 8, Issue 7 Ver.11; Pp 69-74.

[5] Onoh, P.A, Omeire, C.O, Echetama, J.A, Nwaihu, E.C, Ugwoke, F.O and Akalonu, E.C (2016) Dry season vegetable production by women of Okigwe Agricultural zone of Imo State, Nigeria; Nigerian Journal of Agriculture, Food and Environment; 2(3): 89-94.

[6] Mazza, M, Ekumankama, O.O, Okezie, C.A (2015) Effect of Second National Fadama development project on farmers' productivity in Imo State, Nigeria; Journal of Natural Sciences Research 5 (3) (2015), pp.69-74.

[7] Usman, J and Bakari, U.M (2013) Profitability of Dry Season Tomato (Lycopersicon esculentum Mill.) Production in Fufore Local Government Area of Adamawa State, Nigeria; The International Journal of Engineering and Service (IJES); Vol 2, Issue II, Pp $113-117$

[8] Ehirim, N.C, Osuji, E.E, Obasi, I.O, Ukoha, I.I, Maduike, I.A, Ejike, R.D and Oguegbuchulam, M.N (2014); Profitability of Okra Production and Marketing in Imo State; International Journal of Agric and Rural Dev. SAAT, FUTO

[9] Osuji, E.E, Ohajianya, D.O, Ehirim, N.C, Eze, E.U (2012) Effects of Land Use Patterns on Agricultural Productivity in Imo State, Nigeria; International Journal of Food and Agricultural Research; Vol. 9 No (1) ISSN: 0189-7136.

[10] Samshunnahar, M, Romaza, K and Serajul, I(2016) Profitability of small-scale tomato (Lycopersicon esculentum) production in some selected areas of Bangladesh; The Agriculturists 14(1): 73-86; ISSN 2304-7321 (Online); A Scientific Journal of Krishi Foundation.

[11] Tsoho, B.A and Salau, S.A (2012) Profitability and constraints to dry season vegetable production under Fadama in Sudan Savannah ecological zone of Sokoto State, Nigeria: Journal of Development and Agricultural Economics; Vol.4(7), Pp. 214-222

[12] Ajayi, A,R and Nwalieji, H.U (2010); Impact of the Anambra State FADAMA Project Phase 1 on the socio-economic life of the rural farmers; Journal of Human Ecology 29(2): 129-139.

[13] Sanusi, M.M and Ayinde, I.A (2013) Profitability of pepper production in Derived Savannah Zone of Ogun State, Nigeria; International Journal of Agriculture and Forestry (IJAFS) 4:2:401-410.

[14] Nwadukwe, P.O (2000) Fadama Programme in Anambra State; Concepts, principles and practices; Paper presented at the Fadama Sensitization Workshop organized by the ASADEP, Awka, Nigeria, 14 November, pp. 1-6.

[15] Afolami, C.A and Ayinde, I.A (2002) Economics of tomato production in Yewa North Local Government Area of Ogun State, Nigeria. Agro-Science Journal of Tropical Agriculture Food, Environment and Extension, 1(1\&2): 17-23.

[16] Adewumi, M.O, Omotesho, O.A (2002) An analysis of production objective of small rural farming households in Kwara State, Nigeria; Journal of Rural Development. 25 (winter): pp. 201-211.

[17] Ofor, M.O., Obiefuna, J.C., Ibeawuchi, I.I., Ihejirika, G.O., Okoli. N.A, Alagba, R.A. and Dialaoke, S.A, (2015) Post harvest Handling and Value Addition in Vegetable Production., International Journal of Agriculture and Rural Development. 18 (2): 
2292-2298.

[18] Imoh, A.N and Ajaero, J.P (2007) Rural Women Involvement in Dry Season Vegetable Production and Marketing in Ezinihitte Local Government Area of Imo State. Nigeria; GAEP, Vol.3, No. 12 ( pp. 9-12).

[19] Onu, J.I, Amaza, P.S and Okumadewa, F.Y. (2000) Determinants of Cotton Production and Economic Efficiency in Nigeria; African Journal of Business and Economic Research; 112, 34-40.

[20] Mgbada, J.U (2010) Agricultural Extension: The Human Development Perspective; Computer Edge Publishers, Enugu; 298-299.

[21] Balogun, O.L., Adeoye, A., Yusuf, S.A., Akinlade, R.J., and Carim Canni (2012) Production Efficiency of Farmers under National Fadama 11 Project in Oyo State, Nigeria. International Journal of Agricultural Management and Development (IJAMAD)

[22] Nwaobiala, C.U and Ogbonna, M.O (2014) Adoption Determinants and Profitability Analysis of Okra Farmers in Aninri Local Government Area of Enugu State, Nigeria; Discourse Journal of Agriculture and Food Sciences www.res journals.org JAFS; ISSN: 2346-7002; Vol.2 (1): 1-10.

[23] Akinbile, L.A. and Ndaghu, A.A.T (2000) Poverty Level and Poverty Alleviation Strategies of Farm Families; Michika Local Government Area of Adamawa State, Nigeria; Journal of Economics and Rural Development; 41(2), 101-109.

[24] Adejo, P.E, Edoka, M.H and Adejo, S.O (2012) Indigenous Practices and the Challenges of Climate Change among Small-Scale Farmers in Dekina Local Government Area of Kogi State, Nigeria. Proceedings of 17th Annual National of the Agricultural Society of Nigeria (AESON), held at University of Nigeria, Nsukka; 11-14th March, 70-77.

[25] Williams, P.A., Tete-Larbi, R., Yeboah, I., and Frempong, G.K (2018); Smallholder farmers experiences of climate variability and change in pineapple production in Ghana: Examining adaptation strategies for improved production; Journal of Agricultural Extension and Rural Development, 10: 35-43.

[26] Onyewaku, C.F and A.C. Mbuba (1991) The Adoption of the seed-Yam Minisett Multiplication Technique by farmers in Anambra State, Nigeria. The Nigerian Journal of Agricultural Extension, 6 (1 and 2).

[27] Challa, M (2013) Determining Factors and Impacts of Modern Agricultural Technology Adoption in West Wollega, Munich, GRIN Publishing GmhH, http://www.grin.com/en/e-book/280336/determining -factors-and-impacts-of-modern-agricultural-technology-adoption.

[28] Eke-Okoro, O.N and Njoku, D.N (2012) A Review of Cassava development in Nigeria: 1940-2010; ARPN J.Agric.Bio.Sci 7(1): $59-65$

[29] Olukosi, J.O and Erhabor, P.O (2008); Introduction to Farm Management Economics: Principles and Applications. Zaria: Agitab Publishers.

[30] Okeleye, S.O., Olorunfemi, F.B., Sogbeji, J.M., Aziadekey, M (2016) Impact assessment of flood disaster on livelihood of farmers in selected farming communities in Oke-Ogun region of Oyo State, Nigeria; International Journal of Scientific Engineering Research, 7 (8), 2067-2083.

[31] Spaldon, S, Samnotra, R.K and Chopra, S (2015) Climate resilient technologies to meet the challenges in vegetable production; International Research on Current and Academic Review 3 (2) 28-47.

[32] Williams, P.A., Crespo, O and Essegbey, G.O (2017) Economic implications of a changing climate on smallholder pineapple production in Ghana; Journal of Economics and Sustainable Development, 8: 34-43. 